\title{
Tolterodine Tartrate
}

National Cancer Institute

\section{Source}

National Cancer Institute. Tolterodine Tartrate. NCI Thesaurus. Code C29504.

The tartrate salt form of tolterodine, a benzhydryl compound and a muscarinic receptor antagonist possessing both antimuscarinic and antispasmodic properties. Both tolterodine and its active metabolite, 5-hydroxymethyltolterodine, competitively blocks muscarinic receptors, thereby inhibiting acetylcholine receptor binding. This antagonistic action results in an increase in residual urine, reflecting an incomplete emptying of the bladder, and a decrease in detrusor pressure, indicating an antimuscarinic action on the lower urinary tract.. The 5-hydroxymethyl metabolite appears to contribute significantly to the therapeutic effects. 